\title{
Progress on Nanomaterials for Photoelectrochemical Solar Cells: from Titania to Perovskites
}

\author{
Indriana Kartini $^{1}$ \\ ${ }^{1}$ Department of Chemistry, Gadjah Mada University, Yogyakarta - Indonesia
}

\begin{abstract}
Solar cells have been the queen of alternative renewable energy for the earth. From silicon-based solar cells to the new generation of perovskite-based solar cells, the choice and performance of the materials of the corresponding cells are still the focus of research interest. Amongst, photoelectrochemical (PEC) solar cells trigger the use and exploration of nanomaterials to boost their cell's performance. This short review focus on the development of nanomaterials used for PEC, from nanoparticles to the one-dimensional titanium dioxide (titania) such as nanofibers and nanotubes, as well as the hybrid system with the perovskite halide. The search for light-harvesting materials is also included especially natural dyes. The review ends with a strategy to marry the natural dyes' potential with the sophisticated structure of nanomaterials to result in an efficient natural dyes PEC solar cells.
\end{abstract}

Keywords: photoelectrochemical solar cell; nanostructured; $\mathrm{TiO}_{2}$; perovskite; dye-sensitized.

\section{Photoelectrochemical Solar Cells}

Wafer-based silicon solar cells have been in the market for years, however, the complexity of the mass production for those cells, resulted in the uncompetitiveness of such cells to the fossil's fuel. Therefore, the search for a new generation of efficient and cost-effective photovoltaic (PV) technology is still in demand. One of the breakthroughs in PV technology is the invention of the photovoltaic cell based on photoelectrochemistry by Gratzel et al. [1], called photoelectrochemical (PEC) solar cells or more popular as the dye-sensitized solar cells (DSSC). Even the later's name is more popular, here, we continuously mention the PEC solar cells to indicate the basic principle of such a solar cell.

The first PEC solar cells relied on a thin-layer of nanoparticle titanium dioxide or titania (TiO2) with mesoporous structure as the wide bandgap semiconductors and ruthenium $(\mathrm{Ru})$ complex as the sensitizer/dye. The concept of sensitization by the dye makes it possible to obtain an electric current by utilizing energy that is lower than the energy gap of semiconductor material, which is the visible part of sunlight. A PEC cell is constituted of three parts, namely the working electrode, the counter electrode and redox electrolyte. The ruthenium complex is adsorbed on a thin layer of porous semiconductor material, such as titania and both act as the working electrode. While the conductive glass coated with platinum or gold or carbon is used as the counter electrode. Meanwhile, the oxidation-reduction system pair of I-/I3- solution acts as an electrolyte solution.
The complex compound of ruthenium dye is in charge of absorbing sunlight radiation while the thin layer of titania as a charge for electron injection results from the dye sensitizer. Sunlight radiation that hits the dye will excite the ground state electron of the dye (D) to the level of excitation ( $\left.D^{*}\right)$. The excited electrons seek stability towards nearby lower energy levels, which is the conduction band (CB) of the semiconductor nanoparticle titania and are transmitted through the internal structure of the titania pore to generate electrical energy. The excited electrons of the dyes are immediately replaced by electrons resulting from the redox electrolyte solution, a redox couple of I-/I3-. The cycle continues and currents are generated in the solar cell device system (Fig. 1).

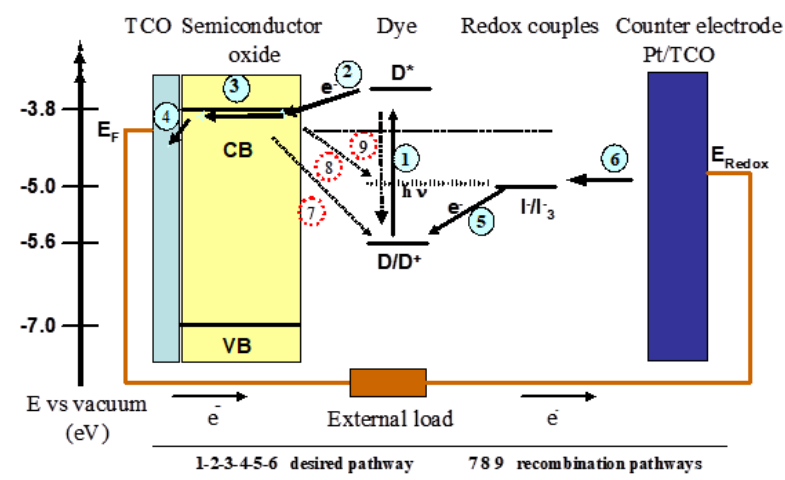

Fig. 1. Work principle of photoelectrochemical solar cells (modified from [2])

Photosensitization process as depicted in Figure 1 consists of desired and undesired pathways. The undesired pathways comprise the back reaction of the

\footnotetext{
* Corresponding author: indriana@ugm.ac.id
} 
injected-electrons with the oxidized state of the dye (pathway 7) or with the oxidized species in redox electrolyte (pathway 8). The electron injection occurs in the femtosecond time regime [3, 4], while the dye regeneration is in the nanosecond time process [5]. These processes compete with interfacial recombination from the conduction band (CB) semiconductor, which occurs at nanosecond to millisecond time regime [5-8]; while the other electron losses (pathway 8) have been found to occur in millisecond time regime under 1 Sun illumination [9]. Thus, it is clear that the performance of the PEC solar cell depends on the competition between forward and backward electron transfer kinetics [2, 10$11]$.

\section{The Quest of Natural Photoefficient Solar Harvesting Materials}

The natural mechanism in photosynthesis inspires technology to harvest and use sunlight continuously as a source of energy for all life on earth. The dyes used for sensitizer should have near black body absorption spectra in order to fully harvesting solar radiation [12, 13]. Shortly, the sensitizers should be panchromatic i.e. absorb visible light of all colors (Fig. 2), have high extinction coefficient, be firmly grafted to the semiconductor oxide surface and inject electrons into the conduction band with a quantum yield of unity, possess suitable ground- and excited state redox properties $(0.5$ and $-0.8 \mathrm{~V}$ vs SCE), exhibit thermal and photochemical stability, and be environmentally friendly.

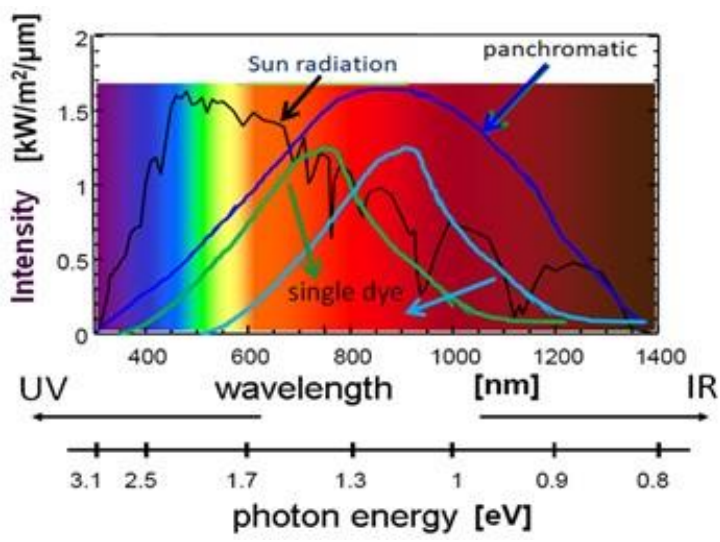

Fig. 2. Illustration concept of the light absorption of single-and panchromatic dyes corresponding to the Sun radiation

Currently, ruthenium metal transition complexes have been used as the benchmark of this system. The electronic transitions originate from metal to ligand charge transfer (MLCT) for poly-pyridyl ligands [14]. The benchmark of the PEC solar cells used the Ru-black complex (black dye) as a sensitizer and the cells produce a global efficiency of $\sim 10 \%$ [15]. The dyes with wide electronic absorption characteristics in the visible light region of the spectrum of sunlight theoretically absorb more solar radiation and are a good sensitizer. Ruthenium complex is a synthetic dyestuff whose manufacturing process requires quite high synthesis skills and in its application, a high level of yield purity is needed to obtain optimum solar cell performance. This type of sensitizer is very unstable and requires very high purity $(\sim 90 \%)$ to be able to work as a sensitizer. As a result, the preparation of complex ruthenium-based sensitizers requires relatively high production costs and professional synthesis skills. Therefore, Ru-black was not developed further on the scale of mass production.

A high level of toxicity was also found for ruthenium dyes [16]. All ruthenium compounds are very toxic and carcinogenic. In addition, the use of $\mathrm{Ru}$ complex as a sensitizer requires a thin layer of $\mathrm{TiO} 210 \mathrm{~m}$ or more to achieve a $10 \%$ efficiency of solar cells. To overcome the potential toxicity of the inorganic ruthenium complex that is used as a sensitizer, alternative benign sensitizers need to be sought. Several studies have been successfully carried out using full organic dyes [17], Znporphyrins $[18,19]$ or replacing the ruthenium with other earth-abundant metals [20], such as iron (Fe) [2122] and copper $(\mathrm{Cu})$ [23] as the solar cell sensitizers.

Most organic compounds are derived from biological sources (natural dyes), namely plants. Natural dyes can be obtained by simple water or alcohol-based solvent extraction from the root, leaves, petal flower, fruit pericarp, bark, and so on. Natural dyes are mostly composed of organic compounds which have a high extinction coefficient character so they can be used in small amounts. High extension coefficient values indicate the ability to absorb solar energy in the UV-Vis region with high intensity. Besides, natural dyes have non-toxic properties, friendly to the environment and abundant availability in nature. Thus, they are costeffective and simple production.

The use of dyes from fruit and vegetable extracts will compete with food, while the extracts of flowers and leaves have a small percentage so that they require large amounts of resources [16]. Therefore, sources of natural dyes are directed towards the use of dyestuff-producing plants that are not competitive with food and have a large percentage of content. Some organic compounds/dyes that can be used as solar cell sensitizers may contain tannin [24], anthocyanin, betalain, flavonoids, carotenoid, and flavonoid [25]. The chemical structure of those compounds is rich in the hydroxyl groups which is useful for bonding to the titania. Among them, the carotenoid group provides higher efficiency than the other groups. One of the plants producing natural dyes of the carotenoid group that does not compete with food plants is annatto or achiote (Bixa Orellana L.). The membrane of the annatto seed contains the main dyes included in the carotenoid group, namely bixin and norbixin $[26,27]$. The bixin content in achiote extract reaches $97 \%$, while the rest is norbixin [28]. Like dyes in general, bixin and norbixin also have the ability to absorb energy in the UV-Vis region due to the presence of chromophore groups in conjugated systems and carbonyl groups [27]. In addition, the source of dyes from achiote seeds has abundant availability and does not compete consumptively and aesthetically with some types of fruits, vegetables, and fruits which are also a source of dyes. Other potential natural dyes are to extract anthocyanin from the pericarp of mangosteen fruit [25]. However, the anthocyanin from mangosteen is sensitive 
to the solution acidity. A stable extract can be obtained from acidic ethanol [25, 29].

Chlorophylls from algae [30] have resulted in poor sensitization effects. Since algae are easy to be cultivated, another dye active ingredient from algae is interesting to be further explored. Algae dyes have also been proven to be used as textile dyes and have a resistance to photobleaching.

Extracts of natural dyes commonly used as batik dyes have also been shown to be able to function as sensitizers in the PEC solar cell system, although the generated current is still relatively small [31], comparable to the chlorophyll from algae. Examples of natural dyes used for PEC solar cells are listed in Table 1.

Table 1. Some selected natural dyes for photoelectrochemical solar cells.

\begin{tabular}{|c|c|c|c|c|}
\hline Resources & $\eta^{*}(\%)$ & $\begin{array}{c}\text { Active } \\
\text { ingredient }\end{array}$ & & Ref \\
\hline Rhododendron & 0.57 & carotenoid & resing & [25] \\
\hline China redbud & $0.1-0.2$ & chlorophyll & & [25] \\
\hline Achiote seed & 0.37 & $\begin{array}{l}\text { carotenoid } \\
\text { bixin }\end{array}$ & & [26] \\
\hline Achiote seed & 0.13 & $\begin{array}{l}\text { carotenoid } \\
\text { norbixin }\end{array}$ & & \\
\hline Chrysanthemum & 0.01 & xanthophyl & & {$[32]$} \\
\hline $\begin{array}{l}\text { Mangosteen } \\
\text { pericarp }\end{array}$ & 1.17 & $\begin{array}{l}\text { anthocya- } \\
\text { nin }\end{array}$ & & [25] \\
\hline Algae** & 0.004 & chlorophyll & & [28] \\
\hline Batik dyes*** & 0.02 & phenolic & & [31] \\
\hline
\end{tabular}

* Solar cell efficiency, ${ }^{* *}$ various methanol extract of: Halymenia agardhii De Toni, Amphiroa foliacea Lamoroux, Hypnea espery Bory and Sargassum mclurei Setchell $* * *$ various n-hexane/acetone extract of: Terminalia bellirica(gaertn)roxb; Ceriops tagal; Maclura cochinensis

The use of natural dyes as a sensitizer will involve making and purifying dyes more easily and quickly so as to reduce production costs, reduce the risk of solar cell toxicity and involve an environmentally friendly manufacturing process. Some also can be extracted from fruit waste $[25,26]$, thus it is green technology. Improved efficiency is still intensively researched by employing a cocktail of dyes [32-34], adsorbed dyes on clay [35], optimizing solvent extraction [36]. Amongst, the combination of dyes has shown two to three times increased efficiency, while the use of clay has decreased the cell efficiency. Later, the focus to improve the cell performance will be on the choice of the semiconductor nanostructure. It has been shown that $\mathrm{TiO} 2$ is still superior compared to the $\mathrm{ZnO}$ semiconductor as the photoanode materials [37]. Therefore, the discussion will focus on the improvement of natural dyes PEC solar cells due to the use of nanostructured titania.

\section{Nanostructured Titania and Natural Dye Sensitizers for PEC Solar Cells}

Another component that influences the PEC solar cell performance is the wide bandgap semiconductor which is used as the photoanode. The most widely used broadband band semiconductor is $\mathrm{TiO}_{2} . \mathrm{TiO}_{2}$ is a crystalline material that has bandgap energy $\left(\mathrm{E}_{\mathrm{g}}\right)$ in the range of $3.0-3.2 \mathrm{eV}$. The crystalline phase of $\mathrm{TiO}_{2}$ found in nature includes anatase, rutile, brookite, and $\mathrm{TiO}_{2}-\mathrm{B}$. Among all the crystalline $\mathrm{TiO}_{2}$ phases, anatase is the most photoactive crystalline phase. The energy of the upper $\mathrm{TiO}_{2}$ band gap is $3.2 \mathrm{eV}$, higher than rutile (3.0 eV). The width of the $\mathrm{TiO}_{2}$ band gap gives the nature of photostability due to the electron recombination.

The ability of $\mathrm{TiO}_{2}$ as a photoanode is also influenced by its morphology. Morphology in nano dimensions that produce large surface areas can optimize electron transport [38]. Various studies have been developed regarding the type of nanomaterial titania. First breakthrough on PEC solar cells has been achieved [1] due to the use of nanoparticle titania with porous structure. Then, the nanostructures of one-dimensional (1-D) morphology with a vertical orientation to the substrate are believed to enhance the efficiency of the generated electrical energy. Wang et al. [39] reported that the $\mathrm{TiO}_{2}$ nanorod photoanode gave a value of Voc $0.802 \mathrm{~V}$, Isc $7.01 \mathrm{~mA}$ and efficiency of $2.9 \%$, whereas with $\mathrm{TiO}_{2}$ nanowire produced Voc $0.752 \mathrm{~V}$, Isc $3.73 \mathrm{~mA}$ and efficiency of $1.81 \%$ [40]. The $\mathrm{TiO}_{2}$ nanotube photoanode gave characteristic values of Voc $0.846 \mathrm{~V}$, Isc $\sim 9.63 \mathrm{~mA}$ and efficiency of $4.03 \%$ [41]. Bijarbooneh et al. [38] used mesoporous $\mathrm{TiO}_{2}$ nanofibers and obtained Voc $0.76 \mathrm{~V}$, Isc $15.23 \mathrm{~mA}$ and were able to increase energy efficiency from $7.28 \%$ to $8.14 \%$. Based on these studies, it was found that the use of semiconductors with 1-D morphology (nanorod, nanotube, nanofiber) provides higher solar cell efficiency. This is because $1-\mathrm{D}-\mathrm{TiO}_{2}$ photoanode has a large surface area so that it is able to adsorb more dyes. The dye adsorption is a monolayer adsorption, so the large surface area is beneficial. The more dyes that can be adsorbed will increase the energy absorption so that more photons can be converted into currents. 1-D morphology also provides direct electron transport from the dye to the conducting electrode as depicted in Figure 3. Thus, reducing inefficient zig-zag electron transpor and electron trapping. However, the 1-D morphology must be aligned perpendicularly to the conducting glass substrate. Recent result has shown that nanotube structure provided long electron lifetimes and good pathways for electron percolation [42]. 


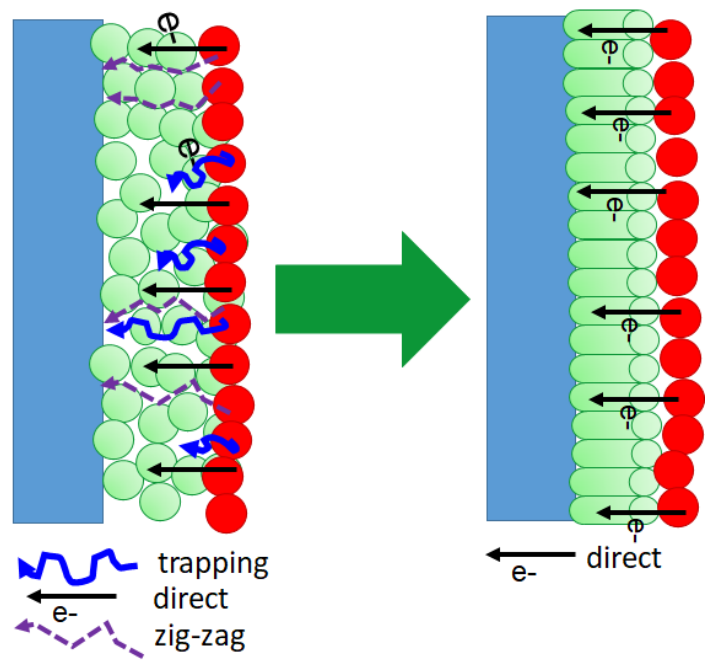

Fig. 3. Illustration concept of electron transport modes transition from the 3-D nanoparticles (left) titania to the 1-D (right) nanotubes structure

Calcined electrospinning $\mathrm{TiO}_{2}$ nanofiber using polyvinylpyrrolidone (PVP) polymers (molecular weight of $1.3 \times 10^{6}$ ) and titanium (IV) isoproxide precursors has produced $\sim 4.2 \%$ electrical efficiency with a ruthenium dye as the sensitizer [43]. The electrospinning was performed at a voltage of $30 \mathrm{kV}$ with a flow rate of 1 $\mathrm{mL} / \mathrm{h}$ and a needle distance to the collector of $10 \mathrm{~cm}$. Fiber thickness of the electrospinning titania has affected the energy conversion. $3.3 \%$ conversion has been achieved by $15 \mu \mathrm{m}$ thick of electrospinning titania [44]. Improved electron lifetimes for the composite film of titania nanoparticle-nanofiber has also been demonstrated [45].

The feature of 1-D nanostructure, then, inspires pathway to increase the conversion efficiency of natural dye PEC solar cells. The cell performance of nanotubes titania was three-times higher than that constructed from nanoparticle titania (P25) using mangosteen pericarp ethanol extract as the sensitizer [46]. Interesting discussion on the electron pathway for 1-D nanostructured materials can be found in Kamat et al. [47]. So far, researches on natural dyes PEC solar cells employing the sophisticated 1-D nanostructure are rarely studied. They are mostly focused on the passion to search for highly efficient natural dyes. To date search on the efficient solar harvesting materials is directed to the metal halide perovskite nanomaterial. This nanomaterial has interesting features to be used as both the light absorber and the photocurrent generator, so it has dual role, replacing the sensitizer dyes and the semiconductor oxides. The last discussion will be focused on the halide perovskite nanomaterial as the light harvester on the PEC solar cells.

\section{Hybrid Perovskites Titania Solar Cells}

Perovskit is a material with the $\mathrm{ABX}_{3}$ structure formula [48]. The ideal perovskite has a cubic crystal structure with the octahedral $\mathrm{BX}_{6}$ in which ion $\mathrm{A}$ enters intermittently into the octahedral. Methylammonium lead(II) iodide $\left(\mathrm{MAPbI}_{3}\right)$ perovskite is a perovskite with cation $\mathrm{A}$ is an organic cation $\mathrm{CH}_{3} \mathrm{NH}_{3}{ }^{+}, \mathrm{B}$ is a metal cation such as $\mathrm{Pb}^{2+}$, and $\mathrm{X}$ is a halide anion such as $\mathrm{I}^{-}$.

The $\mathrm{MAPbI}_{3}$ perovskite has a band gap energy of $1.55 \mathrm{eV}$, which is equivalent to the absorption at a wavelength of $800 \mathrm{~nm}$ so that this material has absorption in the range of visible radiation [49]. This material can also produce electrons with a fairly high charge mobility that is equal to $7.5 \mathrm{~cm}^{2} \mathrm{~V}^{-1} \mathrm{~s}^{-1}$ and hole mobility around $12.5 \mathrm{~cm}^{2} \mathrm{~V}^{-1} \mathrm{~s}^{-1}$ [42]. In addition, the exciton produced has a weak binding energy of $0.03 \mathrm{eV}$ which means that most will dissociate in the interface layer at room temperature. Recombination occurs on a time scale of hundreds of nanoseconds resulting in a diffusion of long charge carriers, the distance that can be taken before the recombination of the carrier occurs in the range of 100-1000 $\mathrm{nm}$ [50]. Cell structure of the hybrid titania perovskite solar cell using $\mathrm{TiO}_{2}$ nanoparticle as the electron transport material (ETL), silver as a metal contact and SpiroOMeTAD as the hole transport material (HTM) along with the energy diagram is displayed in Figure 4. The energy diagram of the constructed cell with FTO (F-doped tin oxide) glass was obtained from Shalan et al. [51].
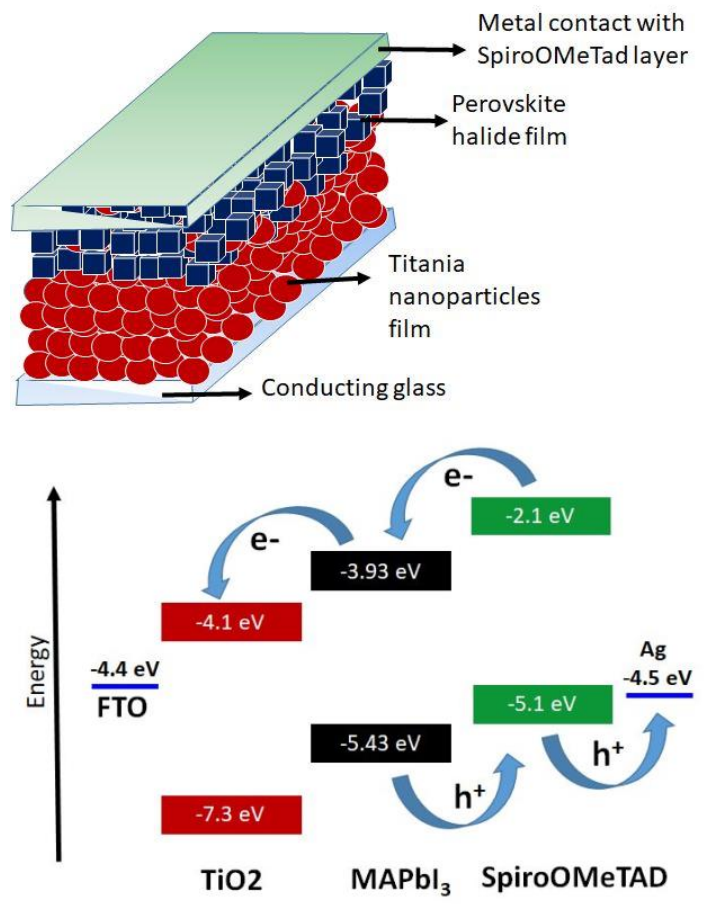

Fig. 4. Illustration of hybrid titania perovskite solar cell and its energy diagram

Methylammonium lead (II) iodide has a high absorption coefficient of light to visible light at various wavelengths to reach near-infrared spectra. At a wavelength of $550 \mathrm{~nm}$, the absorption coefficient of $\mathrm{CH}_{3} \mathrm{NH}_{3} \mathrm{PbI}_{3}$ is $1.5 \times 105 \mathrm{M}^{-1} \mathrm{~cm}^{-1}, 2$ to 3 times higher than the organic dye used so far in PEC solar cells. This allows perovskite to absorb light with higher intensity in layers as thin as 500-600 nm to overcome the thickness limitations $(\sim 2 \mu \mathrm{m})$ of solid-state PEC solar cells [52]. This type of structure can function as an absorber of 
sunlight (a dye sensitizer) in PEC solar cells. $\mathrm{MAPbI}_{3}$ can be prepared at room temperature, so it offers solar cell fabrication technology that is easy and does not require high technology. Typically, the open circuit photovoltage $\left(\mathrm{V}_{\mathrm{OC}}\right)$ of the perovskite solar cells are in the range of $0.9 \mathrm{~V}$ and $1.15 \mathrm{~V}$. Under standard $\mathrm{I}-\mathrm{V}$ measurement and neglecting the entropy losses, the maximum $\mathrm{V}_{\mathrm{OC}}$ is $\sim 300 \mathrm{mV}$ below its band-gap, so for the $\mathrm{MAPbI}_{3}$ with a $1.55 \mathrm{eV}$ band-gap, the VOC max is $1.25 \mathrm{~V}$ [50]. While, the efficiency can reach up to $25.2 \%$ in 2019 for the perovskite solar cell, and $28.0 \%$ for tandem cells with silicon-based solar cells [53]. These attractive features of the perovskite solar cells lead to the effort of marrying the cells to the natural dye PEC solar cells.

The perovskite halide can be used as a co-sensitizer of natural dyes to boost the PEC solar cell efficiency using natural-dyes sensitizers. Just recently, perovskite solar cell with a layer of carotene dye resulted in increased efficiency up to $5.01 \%$ [54], compared to the only carotenoid sensitized PEC solar cell which is $\sim 0.57 \%$ [25]. As stated by Gratzel [50], a marriage of the planar and mesoscopic architecture will win in the end. This strategy can be adopted to boost the natural dyes potential which are abundant and environmentally benign.

\section{Concluding remarks}

Solar cell technology is still promising as alternative renewable energy. Compare to the available silicon solar cells, photoelectrochemical solar cells (PEC) offer a feasible production route. Nanomaterial with nanostructure is important to enhance the performance of the PEC solar cells, especially for natural dyes as the sensitizer. Perovskite organic-inorganic hybrid paves the way to the more efficient non-silicon solar cells. The organometallic perovskite halide can be used as the cosensitizer for the more efficient natural dyes PEC solar cells.

\section{Acknowledgement}

This work is supported by The Ministry of Research, Technology, and Higher Education of the Republic Indonesia under the National Competitive Research Grant, International Foundation for Science (IFS) Sweden, Indonesian Toray Science Foundation (ITSF) research grant, and Universitas Gadjah Mada (Kluster Saintek and Departmental research grant).

\section{References}

1. B. O'Regan, M. Gratzel, Nature 353, 737-739 (1991)

2. A. Hagfeldt, M. Gratzel, 95, 49-68 (1995)

3. Y. Tachibana, M.K. Nazeeruddin, M. Gratzel, D.R. Klug, J.R. Durrant, Chem. Phys. 285(1), 127-132 (2002)
4. J.R. Durrant, Y. Tachibana, I. Mercer, J.E. Moser, M. Gratzel, D.R. Klug, J. Res. Phys. Chem. Chem. Phys. 212, 93-98 (1999)

5. S.A. Haque, Y. Tachibana, D.R. Klug, J.R. Durrant, J. Phys. Chem. B 102(10), 1745-1749 (1998)

6. Y. Tachibana, J.E. Moser, M. Gratzel, D.R. Klug, J.R. Durrant, J. Phys Chem. 100(51), 20056-20062 (1996)

7. H. Lindstrom, E. Magnusson, A. Holmberg, S. Sodergren, S.E. Lindquist, A. Hagfeldt, Sol. Energy Mater. Sol. Cells 73(1), 91-101 (2002)

8. S.A. Haque, Y. Tachibana, R.L. Willis, J.E. Moser, M. Gratzel, D.R. Klug, J.R. Durrant, Journal of Physical Chemistry B 104(3), 538-547 (2000)

9. G. Schlichthorl, S.Y. Huang, J. Sprague, A.J. Frank, J. Phys. Chem. B 101(41), 8141-8155 (1997)

10. S.Y. Huang, G. Schlichthorl, A.J. Nozik, M. Gratzel, A.J. Frank, J. Phys. Chem. B 101(14), 2576-2582 (1997)

11. C.S. Ponseca, Jr., P. Chábera, J. Uhlig, P. Persson, V. Sundström, Chem. Rev. 117, 10940-11024 (2017)

12. M.K. Nazeeruddin, P. Pechy, T. Renouard, S.M. Zakeeruddin, R. Humphry-Baker, P. Comte, P. Liska, L. Cevey, E. Costa, V. Shklover, L. Spiccia, G.B. Deacon, C.A. Bignozzi, M. Gratzel, J. Am. Chem. Soc. 123, 1613-1624 (2001)

13. M.Z. Iqbal, S.R. Ali, S. Khan, Sol. Energy 181, 490509 (2019)

14. M.K. Nazeeruddin, A. Kay, I. Rodicio, R. Humphry-Baker, E. Muller, P. Liska, N. Vlachopoulos, M. Gratzel, J. Am. Chem. Soc. 115, 6382-6390 (1993)

15. M.K. Nazeeruddin, P. Pechy, M. Gratzel, Chem. Commun. 18, 1705-1706 (1997)

16. S. Hao, J. Wu, Y. Huang, J. Lin, Sol. Energy 80, 209-214 (2006)

17. S.M. Feldt, E.A. Gibson, E. Gabrielsson, L. Sun,G. Boschloo, A. Hagfeldt, J. Am. Chem. Soc. 132, 16714-16724 (2010)

18. H. Imahori, T. Umeyama, S. Ito, Acc. Chem. Res. 42, 1809-1818 (2009)

19. L.-L. Li, E.E.-G. Diau, Chem. Soc. Rev. 42, 291-304 (2013)

20. B. Bozic-Weber, E.C. Constable, C.E. Housecroft, Coord. Chem. Rev. 257, 3089-3106 (2013)

21. Y. Liu, P. Persson, V. Sundström, K. Wärnmark, Acc. Chem. Res. 49, 1477-1485 (2016)

22. M. Abrahamsson, Photochemistry 44, 285-295 (2017)

23. C.E. Housecroft, E.C. Constable, Chem. Soc. Rev. 44, 8386-8398 (2015)

24. K. Tennakone, G.R.R.A. Kumara, A.R. Kumarasinghe, P.M. Sirimanne, K.G.U. Wijayantha, J. Photochem. Photobiol. A 94(2-3), 217-220 (1996) 
25. H. Zhou, L. Wu., Y. Gao, T. Ma, J. Photochem. Photobiol. 219, 188-194 (2011)

26. N.M. Gomez-Ortiz., I.A. Vazquez-Maldonado, A.R. Perez-Espadas, G.J. Mena-Rejon, J.A. AzamarBarrios, G. Oskam, Sol. Energy Mater. Sol. Cells 94, 40-44 (2010)

27. A. Rios, A. Marcadante, C. Borsalleli, Dyes Pigments 74, 561-565 (2007)

28. J. Smith, H. Wallin, Annatto extracts-chemical and technical assessment report. Available online:ftp://193.43.36.92/ag/agn/jecfa/cta_annatto.p df (2006)

29. I. Kartini, Evana, Chotimah, Asian J. Chem. 22(6), 4501-4510 (2010)

30. I. Kartini, T.D. Wahyuningsih, S. Wahyuningsih, Chotimah, Spectral Sensitization of Titania Surfaces with Methanol Extract Pigments of Algae for Dyesensitized Solar Cells, Proceeding of The First International Seminar on Science and Technology, 24 January 2009, 1359-1365 (2009)

31. I. Kartini, S.I. Heriyanti, Y. Arryanto, Chotimah, Sensitization of $\mathrm{TiO}_{2}$ Films by Indonesian Natural 'Batik' Dyes for Dye Sensitized Solar Cells (DSSC), Proceeding of International Conference on Chemical Sciences (ICCS-2007). MAT-23-5 - ID161 (2007)

32. I. Kartini, L. Dwitasari, T.D. Wahyuningsih, Chotimah, Internat. J. Sci. Eng. 8(2), 109-114 (2015)

33. M.J. García-Salinas, M.J. Ariza, Appl. Sci., 9, 2515 (2019)

34. H. Chang, Y.J. Lo, Sol. Energy 84(10), 1833-1837 (2010)

35. N.O. Saelim, R. Magaraphan, T. Sreethawong Ceram. Inter. 37(2), 659-663 (2011)

36. R. Hemmatzadeh, A. Mohammadi, J. Theor. Appl. Phys. 57, 1-7 (2013)

37. G.N.M. Ortiz, V.I.A. Maldonado, P.A.R. Espadas, M.G.J. Rejon, A.J.A. Barrios, G. Oskam, Sol. Energy Mater. Sol. Cells 94, 40-44 (2010)

38. F.H. Bijarbooneh, Y. Zhou, Z. Sun, Y.U. Heo, V. Malgras, APL Mater. 1(032106), 1-7 (2013)

39. J. Wang, E.M. Jin, J.Y. Park, W.L. Wang, X.G. Zhao, H.B. Gu, Nanoscale Res. Lett. 7, 98 (2012)

40. Z. Wei, Y. Yao, T. Huang, A. Yu, Int. J. Electrochem. Sci. 6, 1871-1879 (2011)

41. N.A.F. Freitas, J.N. Freitas, H. Winnischofer, Dye Sensitized Solar Cells based on Titania Nanotubes and a Solid-State Electrolyte (Universidade Estadual de Campinas-Campinas SP Brazil, 2013)

42. G. K. Mor, K.Shankar, M. Paulose, O.K. Varghese, C.A. Grimes, Nano Lett. 6(2), 215-218 (2006)

43. A.S. Nair, R. Jose, Y. Shengyuan, S. Ramakrishna, J. Colloid Int. Sci. 353, 39-45 (2011)

44. J. Li, W. Xu, Y. Shi, Trans. Control Mech. Sys. 1(6), 235-238 (2012)
45. E.M. Jin, X.G. Zhao, J-Y. Park, H-B. Gu, Nanoscale Res. Lett. 7, 97 (2012)

46. I. Kartini, Evana, Sutarno, Chotimah, Adv. Mater. Res. 896, 485-488 (2014)

47. P.V. Kamat, K. Tvrdy, D.R. Baker, J.G. Radich, Chem. Rev. 110, 6664-668 (2010)

48. J.M. Frost, K.T. Butler, F. Brivio, C.H. Hendon, van M. Schilfgaarde, A. Walsh., Nano Lett. 14, 2584-90 (2014)

49. T. Baikie, Y.N. Fang, J.M. Kadro, M. Schreyer, F.X. Wei, S.G. Mhaisalkar, M. Grätzel, T.J. White, J. Mater. Chem. A 1, 5628-5641 (2013)

50. M. Grätzel, Nat. Mater., 13, 838-42 (2014)

51. A.E. Shalan, S., Narra, T. Oshikiri, K. Ueno, X. Shi, H.P. Wu, M.M. Elshanawany, E.W.G. Diau, H. Misawa, Sustain. Energy Fuels 1(7), 1533-1540 (2017)

52. Z. Yang, W.H. Zhang, Chinese J. Catal. 35, 983-988 (2014)

53. NREL efficiency chart, accessed on 25 September 2019, https://www.nrel.gov/pv/assets/pdfs/bestresearch-cell-efficiencies.20190802.pdf

54. A. Dey, A. Dhar, S. Roy, B.C. Das, Mater. TodayProc. 4, 12651-12656 (2017) 